\title{
Red blood cells in cerebrospinal fluid as possible inhibitory factor for enterovirus RT-PCR
}

\author{
Presença de hemácias no líquido cefalorraquidiano como possível fator inibitório da \\ RT-PCR para detecção de enterovirus
}

Sérgio Monteiro de Almeida ${ }^{1,2,3}$, Sônia Mara Raboni', Meri Bordignon Nogueira', Luine R. Renaud Vidal ${ }^{1}$

\begin{abstract}
The presence of hemoglobin in samples are considered an important inhibitory factor for polymerase chain reaction (PCR). The aim of this study was to examine the influence of red blood cells (RBC)s in cerebrospinal fluid (CSF) as an inhibitory factor to reverse transcription polymerase chain reaction (RT-PCR) for enteroviruses (EV). Forty-four CSF samples from patients showing characteristics of viral meningitis were assessed for EV by RT-PCR. Viral RNA extracted with guanidine isothyocianate buffer and virus detection was performed by in-house nested PCR. Positivity for EV RT-PCR was higher in CSF samples without RBCs than in samples with RBCs: 13(26\%) and 36(9.2\%), p = 0.001. In the group with positive EVRT-PCR, the mean +SD CSFRBC was $37 \pm 183 \mathrm{cell} / \mathrm{mm}^{3}$; the group with negative results had $580+2,890 \mathrm{cell} / \mathrm{mm}^{3}$ $(p=0.007)$. The acceptable upper limit for CSF RBCs that could not influence RT-PCR was 108 cells $/ \mathrm{mm}^{3}$. CSF samples with negative results for EV RT-PCR have more erythrocytes.
\end{abstract}

Keywords: enterovirus; cerebrospinal fluid; reverse transcriptase polymerase chain reaction; hemoglobins; erythrocytes; meningitis

\section{RESUMO}

A presença de hemoglobina em amostras de fluidos corporais é considerada um fator inibitório importante da reação em cadeia da polimerase (PCR). O objetivo deste estudo era examinar a influencia de hemácias no líquido cefalorraquidiano (LCR) como um fator inibitório da RT-PCR para enterovirus (EV). Quatrocentos e quarenta amostras de LCR de pacientes com características de meningite viral foram avaliados para enterovirus por RT-PCR. RNA viral foi extraído com tampão de isotiocianato de guanidina e a detecção viral foi feita com nested PCR in-house. A positividade do EV RT-PCR no LCR foi maior nas amostras de LCR sem hemácias do que as amostras com hemácias: $13(26 \%)$ e 36 (9,2\%), respectivamente ( $p=0,001)$. No grupo com resultados EV RT-PCR positivo, a media \pm DP do número de hemácias no LCR foi $37 \pm 183 \mathrm{cell} / \mathrm{mm}^{3}$ e no grupo com resultados negativos foi $580 \pm 2.890 \mathrm{cell} / \mathrm{mm}^{3}$ ( $\left.p=0,007\right)$. O limite superior aceitável de hemácias no LCR para não inibir o resultado do PCR foi 108 cells $/ \mathrm{mm}^{3}$. As amostras de LCR com resultados negativos para RT-PCR EV tem mais eritrócitos em comparação com amostras com resultados positivos.

Palavras-chave: enterovirus; líquido cefalorraquidiano; reação em cadeia da polimerase via transcriptase reversa; hemoglobinas; eritrócitos; meningite.

Despite its high sensitivity, polymerase chain reaction (PCR) can still provide false-negative results. The presence of hemoglobin in body fluid samples has been considered as an important inhibitory factor for PCR. Other factors include the quality of samples submitted to the lab, small recovery rates of genetic material from the sample during processing, low specificity of primers, optimization of reagents, failure to use nuclease-free materials, or the presence of a series of PCR inhibitory factors in the samples. Various body fluids such as saliva, urine, serum, stool, amniotic fluid, and cerebrospinal fluid (CSF) contain intrinsic agents that can inhibit $\mathrm{PCR}^{1,2,3}$.

Accidental introduction of red blood cells (RBC) in CSF is a frequent complication during CSF puncture, mainly in newborns and in young children. It occurs more frequently among less experienced physicians. The CSF samples with

1Universidade Federal do Paraná, Hospital de Clínicas, Seção de Virologia, Curitiba PR, Brasil;

${ }^{2}$ Faculdades Pequeno Príncipe, Curitiba PR, Brasil;

${ }^{3}$ Instituto de Pesquisa Pelé Pequeno Príncipe, Curitiba PR, Brasil.

Correspondence: Sérgio Monteiro de Almeida; Hospital de Clínicas - UFPR, Seção de Virologia, Setor Análises Clínicas; Rua Padre Camargo, 280; $80060-240$ Curitiba PR, Brasil; E-mail: sergio.ma@ufpr.br

Conflict of interest: There is no conflict of interest to declare.

Received 31 December 2015; Received in final form 13 June 2016; Accepted 14 July 2016. 
puncture accidents are frequently referred to laboratories, especially in teaching hospitals, and could be responsible for the large number of false-negative PCR results for CSF, thus limiting the value of its interpretation ${ }^{3}$.

To the authors' knowledge, there are no studies that analyze the effect of RBCs on the positivity for enterovirus (EV) reverse transcription polymerase chain reaction (RT-PCR) in CSF; this is the first study that tries to establish an acceptable maximum number of RBCs in CSF that does not influence the positivity of PCR. The aims of this study are to determine the influence of red blood cell presence in CSF as an inhibitory factor to the RT-PCR reaction for EV, and to establish an acceptable upper limit for the number of RBCs in CSF that does not influence RT-PCR positivity.

\section{METHODS}

Four hundred and forty CSF samples were collected by lumbar puncture from patients with clinically suspected meningitis; CSF samples were referred to the virology laboratory in less than 24 hours on ice and were stored in an $\mathrm{RNA} / \mathrm{DNase}$-free and sterile tube at $-70^{\circ} \mathrm{C}$ until molecular analysis. The study was approved by the Ethical and Research Committee on Human Beings from the Hospital de Clínicas, UFPR.

Inclusion criteria - CSF samples were included in the study based on the biochemical and cytological characteristics of viral meningitis in CSF, which are as follows: white blood cells (WBCs) $\geq 5$ cells $/ \mathrm{mm}^{3}$ with a predominance of lymphocytes; normal CSF glucose levels (> $45 \mathrm{mg} / \mathrm{dL}$ ); and CSF lactate level $<3.5 \mathrm{mmol} / \mathrm{L}^{4}$.

Exclusion criteria - [1] Clinical diagnosis of encephalitis, defined as acute onset $(<3$ weeks), the presence of fever $\left(>38^{\circ} \mathrm{C}\right)$, and signs or symptoms that suggested brain parenchyma involvement (consciousness and/or personality alterations, seizures or focal neurological signs). [2] Samples with CSF biochemical and cytological findings indicative of bacterial meningitis: WBCs $>5$ cells $/ \mathrm{mm}^{3}$ with predominance of neutrophils, low CSF glucose levels (< $45 \mathrm{mg} / \mathrm{dL}$ ), CSF lactate $>3.5 \mathrm{mmol} / \mathrm{L}$. [3] Samples stored improperly, i.e., non-refrigerated samples or those sent improperly to the virology section. [4] Identification of an etiologic agent other than enterovirus in CSF.

\section{Cellular and biochemical CSF characteristics}

Total CSF protein was quantified by the sulphosalicylic acid turbidometric method and CSF glucose levels were assessed using the enzymatic method. The total cell counts of WBCs and RBCs were quantified using a Fuchs Rosenthal chamber. For differential cell counts, CSF samples were concentrated in a cytospin and the slides were stained by the May Grünwald-Giemsa technique.

\section{Extraction of viral RNA/DNA}

Extraction of viral RNA was performed according to a previously described protocol ${ }^{5}$. Briefly, $200 \mu \mathrm{L}$ of lysis buffer (guanidine isothyocianate [GuSCN], Invitrogen (USA) $4 \mathrm{M}$ ), $0.5 \%$ N-lauroylsarcosine salt solution (Fluka [USA]), $1 \mathrm{mM}$ dithiotreitol (DTT) (Invitrogen [USA]), $25 \mathrm{mM}$ sodium citrate (Sigma [USA]), $20 \mu \mathrm{g} /$ tube of glycogen (Sigma [USA]), and 100 copies of plasmid with pseudo rabies virus used as internal control were added to $50 \mu \mathrm{L}$ of CSF. After vortexing, the tube was incubated at room temperature for 10 minutes. To this, $250 \mu \mathrm{L}$ of isopropyl alcohol $\left(-20^{\circ} \mathrm{C}\right)$ was added, followed by vortexing and centrifugation for 10 minutes at $17,000 \mathrm{rpm}$ at $4^{\circ} \mathrm{C}$. The cell pellet was washed with $500 \mu \mathrm{L}$ of ethanol $70 \%$, and centrifuged as described. The supernatant was discarded and the open tube was incubated at $56^{\circ} \mathrm{C}$ for 10 minutes. The dried pellet was resuspended in ultrapure water and stored at $-70^{\circ} \mathrm{C}$.

\section{Reverse transcription}

Viral RNA was transcribed to obtain cDNA as described previously ${ }^{6}$. The master mix was prepared in a volume of $17.5 \mu \mathrm{L} /$ tube. The mix contained $2.5 \mathrm{mM}$ deoxynucleotide triphosphates (dNTPs), 5X buffer (Invitrogen, USA), 0.1M dithiothreitol (DTT) (Invitrogen, USA), $0.25 \mu \mathrm{L}$ of RNase Out (Invitrogen, USA), and $0.25 \mu \mathrm{L}$ of the reverse transcriptase enzyme Superscript II (Invitrogen, USA). To $10 \mu \mathrm{L}$ of the extracted product, $0.5 \mu \mathrm{L}$ of the enterovirus antisense primer was added. After two minutes at $94^{\circ} \mathrm{C}$, the sample was cooled on ice, and $17.5 \mu \mathrm{L}$ of the mix was added to the tube, which was incubated at $45^{\circ} \mathrm{C}$ for one hour.

Nested PCR enterovirus - The PCR for enterovirus was based on amplification of the 5'-UTR region of the gene, which is a highly conserved region in most enterovirus serotypes ${ }^{7}$. For the first PCR, the primer sequences used were EV1-Reverse 5'GAAACACGGACACCAAAGTAGTCG3' and EV1-Forward 5'CGGTACCTTTGTRCGCCTGTTTTA3'. The amplification was carried out for two rounds. For the first PCR, the master mix contained $10 \mathrm{mM}$ Tris-HCL (pH 8.8), $3.5 \mathrm{mM} \mathrm{MgCl}_{2}, 2.5 \mathrm{mM} \mathrm{KCl}, 1.5 \mathrm{U}$ of Taq polymerase, and 0.5 $\mu \mathrm{L}$ of each external primer in a concentration of $10 \mathrm{pmol}$, and the final volume was adjusted with ultrapure water to 22.5 $\mu \mathrm{L}$, after which $2.5 \mu \mathrm{L}$ of cDNA was added. The amplification was performed using an Eppendorf thermocycler with one cycle at $94^{\circ} \mathrm{C}$ for two minutes, followed by 40 cycles: $94^{\circ} \mathrm{C}$ for 30 seconds, $48^{\circ} \mathrm{C}$ for 30 seconds, and $72^{\circ} \mathrm{C}$ for two minutes, followed by an extension at $72^{\circ} \mathrm{C}$ for 10 minutes. For the second PCR, the primer sequences used were as follows: EV2 - Reverse 5'GGATTAGCCGCATTCAGGG3'; EV2 - Forward 5'CAAGCACTTCTGTTTCCCCG3'. The master mix for the second PCR was similar to that described above and the volume of Taq polymerase used was 0.25 $\mu \mathrm{L}$. The first amplification product had $0.5 \mu \mathrm{L}$ added to $24.5 \mu \mathrm{L}$ of the master mix. The second amplification was performed using an Eppendorf thermocycler with one cycle 
of $94^{\circ} \mathrm{C}$ for two min, followed by 30 cycles of $94^{\circ} \mathrm{C}$ for $30 \mathrm{~s}$, $52^{\circ} \mathrm{C}$ for $30 \mathrm{~s}, 72^{\circ} \mathrm{C}$ for one min, followed by an extension at $72^{\circ} \mathrm{C}$ for 10 minutes. The amplification products were analyzed on a $1 \%$ agarose gel. The expected product size for the enterovirus amplicon was 306-316 bp and that for the internal control, pseudo rabies virus, was $147 \mathrm{bp}$.

The CSF samples were analyzed by RT-PCR for enterovirus detection; the primers used for this study targeted a portion of the 5-NCR, a highly conserved portion in different enterovirus serotypes. The degenerate primer was designed based on the sequences of 13 serotypes of enterovirus (Polio1, Polio2, Polio3, CB1, CB3, CB4, CB5, CA9, CA16, CA21, CA24, CB1, CB3, CB4, CB5, Echo12, and Enterovirus 70).

\section{Statistical analysis}

The samples were divided into the following groups: 1. EV RT-PCR negative $(n=391)$ and EV RT-PCR positive ( $n=49) ; 2$. Without RBCs in the CSF $(n=49)$ and with RBCs in the CSF $(n=391)$.

Comparisons between groups were made using chi-square tests, Fisher's exact tests, and non-parametric methods as appropriate. The acceptable upper limit of RBCs in CSF that could not influence the enterovirus PCR was determined by the receiver operating characteristic (ROC) curve $^{8}$.

Results were considered statistically significant at the $5 \%$ alpha level.

\section{RESULTS}

The mean \pm SD age in the EV RT-PCR negative group was $6.5 \pm 7.4$ years while that in the EV RT-PCR positive group was $6 \pm 5$ years ( $p>0.05)$. The EV RT-PCR negative group had 234 male subjects (59\%) and the EV RT-PCR positive group had 27 male $(56 \%)$ subjects $(p=0.54)$. The two groups were comparable in gender, age, CSF biochemistry characteristics (total protein (TP) and glucoses) and CSF WBC number. The percentage of lymphocytes was higher in the EV RT-PCR negative group, with statistical significance; although in both groups there was a predominance of lymphocytes in accordance with the diagnosis of lymphocytic meningitis (Table 1). Fortynine $(11 \%)$ samples showed amplicons consistent with the expected size (306-316 bp in agarose gel stained with ethidium bromide), while 391 (89\%) samples were negative. In the group with negative RT-PCR findings for EV, the RBC number (mean \pm SD) was $580 \pm 2890$ cells $/ \mathrm{mm}^{3}$ and in the group with positive RT-PCR findings, the RBC number was $37 \pm 183$ cells $/ \mathrm{mm}^{3}$ (MW p = 0.007). The cytological and biochemical characteristics of CSF in both groups are shown in Table 1 and Figure 1.

In the group without RBCs in the CSF, 13 (26.5\%) samples were positive for EV RT-PCR, and in the group with RBCs in the CSF, $36(9.2 \%)$ samples were positive $\left(\mathrm{X}^{2} \mathrm{p}=0.001\right.$;
Table 1. CSF cell and biochemistry characteristics in groups with positive and negative enterovirus RT-PCR.

\begin{tabular}{lccc}
\hline Variable & $\begin{array}{c}\text { EV RT-PCR } \\
\text { Negative }\end{array}$ & $\begin{array}{c}\text { EV RT-PCR } \\
\text { Positive }\end{array}$ & $p$ \\
\hline $\mathrm{N}$ & 391 & 49 & \\
\hline RBC cell/mm & $580 \pm 2890$ & $37 \pm 183$ & 0.007 \\
WBC cell/mm & $163 \pm 271$ & $170 \pm 279$ & 0.799 \\
\hline Neutrophils (\%) & $6 \pm 17$ & $34 \pm 33$ & 0.340 \\
\hline Lymphocytes (\%) & $81 \pm 90$ & $63 \pm 31$ & 0.035 \\
\hline Monocytes (\%) & $17 \pm 33$ & $11 \pm 23$ & 0.821 \\
\hline TP (mg/dL) & $52 \pm 32$ & $54 \pm 44$ & 0.556 \\
Glucose (mg/dL) & $68 \pm 55$ & $71 \pm 33$ & 0.234 \\
\hline
\end{tabular}

Results presented as mean \pm SD. EV RT-PCR: enterovirus reverse transcriptase-PCR; RBC: red blood cell; WBC: white blood cell; TP: total protein.

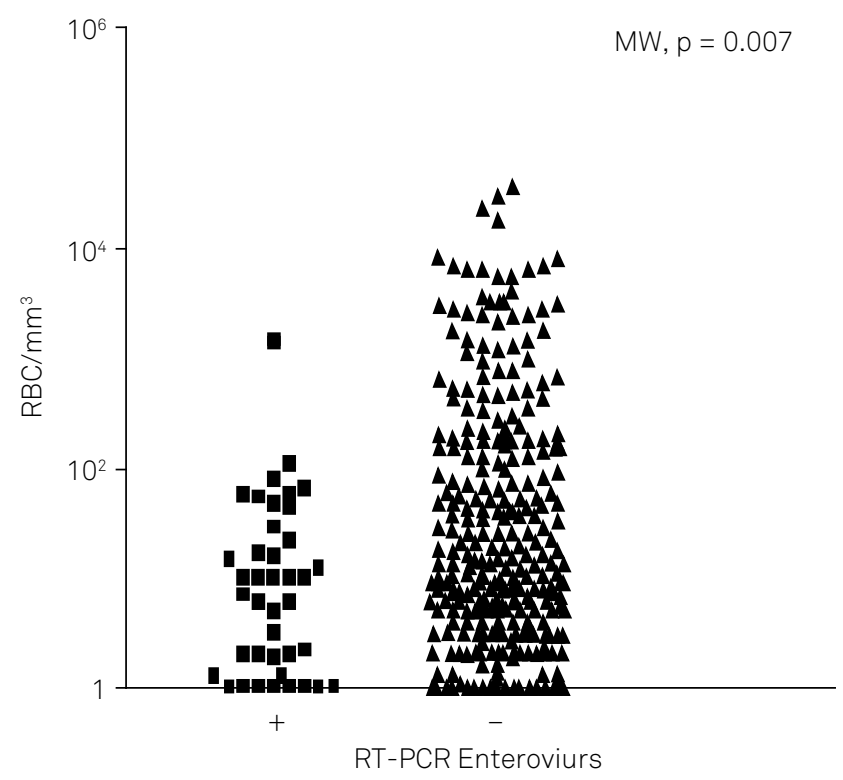

Figure 1. Relationship between the presence of RBCs in CSF samples and the positivity of RT-PCR to enterovirus.

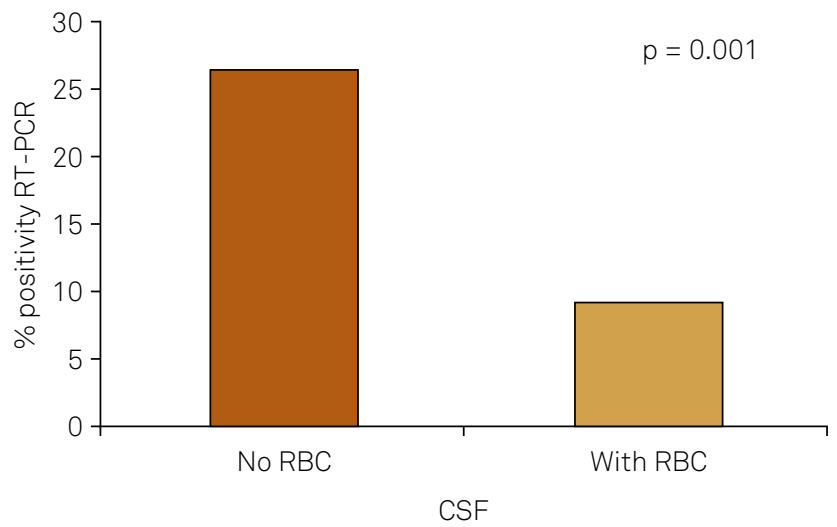

Figure 2. Percentage of enterovirus RT-PCR positivity in groups with and without RBC in CSF samples. 
Figure 2). The acceptable upper limit of RBCs in CSF that could not influence EV RT-PCR was calculated by the ROC curve to be 108 cells $/ \mathrm{mm}^{3}$ (Figure 3 ).

Considering this cutoff to stratify the number of CSF RBCs, 47 (96\%) of CSF samples in the group with a positive EV RT-PCR had CSF RBCs under or equal to 100 cell $/ \mathrm{mm}^{3}$, whereas in the group with a negative EV RT-PCR, 312 (80\%) of CSF samples had RBCs beyond this value ( $\mathrm{p}=0.003$; Table 2$)$. In the EV RT-PCR negative samples, 35 (9\%) of samples had more than $1000 \mathrm{CSF}$ cells $/ \mathrm{mm}^{3}$; in the EV RT-PCR positive samples, only one (2\%) sample had this number.

\section{DISCUSSION}

In this study, RT-PCR for enterovirus was 2.3 times more positive in the group without RBCs in the CSF than in the group with RBCs. According to the ROC curve, the upper limit for RBCs in CSF that could not influence the results was 108 $\mathrm{RBC} / \mathrm{mm}^{3}$. This is considered to be equivalent to a small CSF puncture accident. However, the ROC curve calculated is not ideal due to its closeness with the diagonal line and the small area under the curve (AUC). Stratifying the number of CSF RBCs in both groups, the values are seen to be in accordance with the value provided by the ROC curve.
Traumatic CSF puncture is the accidental introduction of RBCs during CSF collection, and is a frequent complication of CSF puncture. Heme products from the breakdown of erythrocytes may inhibit the PCR, but modest CSF xanthochromia, high protein levels, or high WBC counts do not have a negative impact on CSF PCR testing.

Several other blood constituents are related to the inhibition of PCR, such as heme, hemoglobin, lactoferrin, heparin, and IgG, resulting in the generation of falsenegative results ${ }^{9}$. All these factors, mainly heme and

Table 2. CSF RBC counts (cell//mm $\mathrm{m}^{3}$ ) in the groups with enterovirus RT-PCR positive and negative.

\begin{tabular}{|c|c|c|c|c|c|}
\hline \multirow{2}{*}{ Variable } & \multicolumn{2}{|c|}{ EV RT-PCR Negative } & \multicolumn{2}{|c|}{ EV RT-PCR Positive } & \multirow{2}{*}{$\mathrm{P}$} \\
\hline & $\mathrm{n}$ & $\%$ & $n$ & $\%$ & \\
\hline 0 & 36 & 9.2 & 13 & 26 & 0.001 \\
\hline $0.6-5$ & 159 & 41.0 & 16 & 36 & 0.65 \\
\hline $5-120$ & 70 & 18.0 & 9 & 17 & 1.00 \\
\hline $21-100$ & 47 & 12.0 & 9 & 17 & 0.25 \\
\hline $101-500$ & 34 & 8.7 & 1 & 2 & 0.16 \\
\hline $501-1.000$ & 10 & 2.6 & 0 & 0 & 0.04 \\
\hline$>1000$ & 35 & 9.0 & 1 & 2 & 0.16 \\
\hline
\end{tabular}

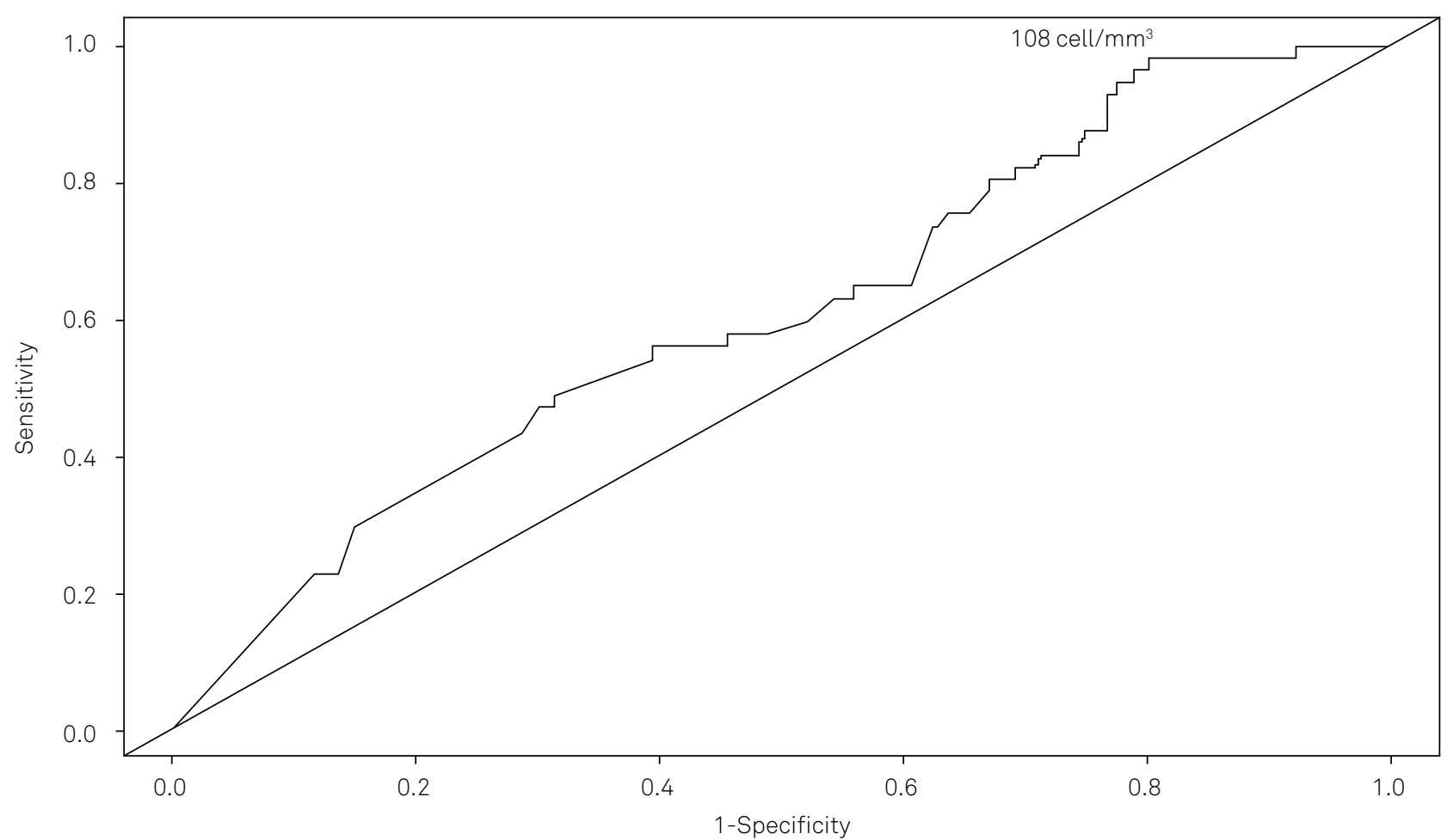

Receiver operating characteristic (ROC) curve of the studied groups. The acceptable upper limit for RBCs in CSF that could not influence enterovirus PCR was $108 \mathrm{cell} / \mathrm{mm}^{3} \mathrm{AUC}=0.61$. The area under the curve (AUC) serves as a single measure, independent of prevalence, which summarizes the discriminative ability of a test across the full range of cut-offs. The greater the AUC, the better the test. A perfect test will have an AUC of 1.0, while a completely useless test (one whose curve falls on the diagonal line) has an AUC of 0.5. Youden's index (J), is the difference between the true positive rate and the false positive rate. Maximizing this index reveals, from the ROC curve, an optimal cut-off point independently from the prevalence. According to its definition, $J$ is the vertical distance between the ROC curve and the first bisector (or chance line).

Figure 3. The ROC curve of the studied group. 
hemoglobin, are present in CSF samples with puncture accidents. These factors may cause competitive inhibition, i.e., binding of an inhibitory factor to an active site of the DNA polymerase, thereby inhibiting amplification.

In general, endogenous polymerase inhibitors are very rarely present in CSF compared to other body fluids or tissues. Nevertheless, false-negative results occur in CSF analysis as well. Factors that contribute to low sensitivity, include low viral load, delay in CSF processing or rapid clearance due to a robust host neutralizing antibody response. False negative results may also occur in the presence of endogenous polymerase inhibitors; especially heme products from artificial blood contamination, which may inhibit PCR, and this should be kept in mind in cases of unexpected negative results, as in suspected herpes simplex encephalitis ${ }^{10}$. There is no validation for extraction and PCR methods with CSF, and even for the volume of CSF that needs to be used.

Heparin and hemoglobin are natural components of blood. A number of publications have shown that hemoglobin has a great inhibitory effect on PCR and similar effects have been reported with heparin as well ${ }^{11,12,13}$. Usually, heparin occurs in insufficient quantities in the blood to be detectable as an anticoagulant.

Hemoglobin is a multichain protein that serves as the oxygen-carrying protein of red blood cells. Hemoglobin is made up of four polypeptides or globin chains: two identical $\alpha$-chains and two identical $\beta$-chains. The globin chains of hemoglobin interact and are connected to each other by the heme group, which contains an iron ion $(\mathrm{Fe} 2+)$ in the center. The heme group with the iron ion has been shown to be involved in inactivating several DNA polymerases in PCR reactions ${ }^{9}$.

An earlier experiment determined that a concentration of $1 \mathrm{mg} \mathrm{ml}{ }^{-1}$ hemoglobin or of $0.013 \mathrm{mg} \mathrm{ml}^{-1}$ heparin had a significant inhibitory effect on PCR amplification. Concentrations of $10 \mathrm{mg} \mathrm{ml}^{-1}$ hemoglobin in water and $1.3 \mathrm{mg} \mathrm{ml}^{-1}$ of heparin in water were therefore selected as suitable inhibitor concentrations for all the tests throughout the study. These concentrations were 1 and 2 orders of magnitude, respectively, higher than the concentrations showing the PCR inhibition effect ${ }^{14}$.

In this study, we used an in-house made buffer for RNA extraction that may explain the high rate of RBC interference in the PCR positive results. We suggest the use of commercial kits for extraction, although studies comparing these assays in CSF are necessary.

Enterovirus is an RNA virus. RNA is more labile than double-stranded DNA, and is more susceptible to inhibitory factors than DNA viruses such as herpesviruses. The impact of RBCs in CSF must therefore be evaluated in DNA viruses ${ }^{10}$. Almost $90 \%$ of acute viral meningitis cases are caused by enteroviruses such as coxsackievirus and echovirus, which have several serotypes ${ }^{15}$, followed by the herpesviridae family of viruses ${ }^{16}$.
The implication of many inhibiting factors in PCR results is well known. In CSF samples collected less than three days after the onset of neurological symptoms, only $12 \%$ samples showed positive results. A higher positivity was observed on the fourth or fifth day ${ }^{1,17}$. In our study, most CSF samples were collected on the second day (median $12 \mathrm{~h})^{18}$, which could explain the high number of negative samples. Additionally, the elevated number of RBCs due to traumatic lumbar puncture in the CSF samples, as well as the presence of hemoglobin, probably had an inhibitory effect generating false-negative results. We excluded CSF samples with a predominance of neutrophils from this analysis, as the aim of this study was lymphomonocytary meningitis. This could have had little impact on the number of positive PCR samples as the samples included in this study were collected with a mean of $12 \mathrm{~h}$.

Although the PCR technique is highly sensitive due to the million-fold amplification of the genomic material present in the tested sample, the exact sensitivity in particular clinical situations is not known for many organisms due to the lack of a gold standard for comparison. For some organisms, the sensitivity is low, leading to false-negative results. Factors that might contribute to the low sensitivity (false negatives) include low viral load due to delay in obtaining the CSF specimen for testing, or rapid clearance due to robust host neutralizing antibody responses. False-negative tests may also occur if endogenous polymerase inhibitors that interfere with PCR are present in the CSF sample ${ }^{10}$.

A variant of classical PCR, called nested PCR, was utilized for the analysis of specimens in which very few viral particles are presumed to be present, such as CSF, with the goal of substantially increasing the sensitivity and specificity of the PCR. In nested PCR, the first PCR is followed by an additional amplification with a second set of primers that are complementary to sequences internal to the sequence targeted by the first set of primers. The replicating virus and viral nucleic acid do not persist indefinitely in infected patients, particularly in immunocompetent patients who mount an effective neutralizing antibody response ${ }^{19}$.

However, most CSF testing is performed in the clinical setting of suspected meningitis or meningoencephalomyelitis within one to two days following the onset of neurologic symptoms, at a time that the yield from PCR testing is likely to be at its peak.

Positive CSF PCR test results have been noted for up to four weeks after onset of clinical symptoms, depending on the pathogen ${ }^{20}$.

The strength of this study is in the substantial number of cases with suspicion of acute lymphocytic meningitis that were analyzed.

The present study is not without limitations; the results must be viewed carefully as other less-frequent viruses that could be related to meningitis were not investigated, such as adenovirus, influenza virus, HIV, measles, rubella, or mumps. 
Other causes of lymphomonocytary meningitis, although less prevalent, could be associated with other infectious agents such as Mycobacterium tuberculosis, Treponema pallidum, Cryptococcus neoformans, Listeria monocytogenes, Brucella spp., Mycoplasma spp., neurocysticercosis, leptospirosis or non-infectious conditions including autoimmune diseases and carcinomatous meningitis, must also be considered ${ }^{4}$. The main limitation of this study is the lack of an optimal gold standard; thus, this is a descriptive comparative study.

In conclusion, the presence of RBCs in CSF with a number greater than $108 \mathrm{cell} / \mathrm{mm}^{3}$ may interfere with the positivity of EV RT-PCR, causing false-negative results. Cerebrospinal fluid samples with negative results for EV PCR have greater numbers of erythrocytes in compared with the samples showing positive results. We stress the importance of observing technical precepts when collecting CSF in order to reduce the number of CSF puncture accidents for greater effectiveness of RT-PCR in diagnosis and treatment.

This study was performed with an in-house extraction using guanidine isothyocianate (GuSCN) buffer. These results are valid for EV and for the in-house extraction kit. We cannot extend the results to DNA viruses such as herpes simplex virus type 1 or 2 that are major causes of sporadic encephalitis. More studies need to be conducted to evaluate the impact of RBCs in CSF using commercial kits and for DNA viruses.

\section{References}

1. Davies NWS, Brown LJ, Gonde J, D Irish, R O Robinson, A V Swan et al. Factors influencing PCR detection of viruses in cerebrospinal fluid of patients with suspected CNS infections. J Neurol Neurosurg Psychiatry. 2005;76(1):82-7. doi:10.1136/jnnp.2004.045336

2. Ochert AS, Boulter AW, Birnbaum W, Johnson NW, Teo CG. Inhibitory effect of salivary fluids on PCR: potency and removal. PCR Methods Appl. 1994;3(6):365-8. doi:10.1101/gr.3.6.365

3. Spreer A. Detection of infectious agents. In: Deisenhammer F, Sellebjerg F, Teunissen CE, Tumani H, editors. Cerebrospinal fluid in clinical neurology. New York: Springer; 2015. p. 131-42.

4. Almeida SM, Nogueira MB, Raboni SM, Vidal LRR. Laboratorial diagnosis of lymphocytic meningitis. Braz J Infect Dis. 2007;11(5):489-95. doi:10.1590/S1413-86702007000500010

5. Casas I, Powell L, Klapper P, Cleator G. New method for the extraction of viral RNA and DNA from cerebrospinal fluid for use in the polymerase chain reaction assay. J Virol Methods. 1995;53(1):25-36. doi:10.1016/0166-0934(94)00173-E

6. Casas I, Tenorio A, Echevarría JM, Klapper PE, Cleator GM. Detection of enteroviral RNA and specific DNA of herpesviruses by multiplex genome amplification. J Virol Methods. 1997;66(1):39-50. doi:10.1016/S0166-0934(97)00035-9

7. Casas I, Pozo F, Trallero G, Echevarría JM, Tenorio A. Viral diagnosis of neurological infection by RT multiplex PCR: a search for entero and herpesviruses in a prospective study. J Med Virol.1999;57(2):145-51. doi:10.1002/(SICI)1096-9071 (199902)57:2<145::AID-JMV10>3.0.CO;2-N

8. Akobeng AK. Understanding diagnostic tests 3: receiver operating characteristic curves. Acta Paediatr. 2007;96(5):644-7. doi:10.1111/j.1651-2227.2006.00178.x

9. Lodish H, Berk A, Kaiser CA, Krieger M, Scott MP, Bretscher et al. Regulating the eukaryotic cell cycle. In: James D, Lodish H, Baltimore D. Molecular cell biology. 4th ed. New York: W. H. Freeman; 2000. p. 51-104.

10. Debiasi R, Tyler K. Molecular methods for diagnosis of viral encephalitis. Clin Microbiol Rev. 2004;17(4):903-25. doi:10.1128/CMR.17.4.903-925.2004
11. Al-Soud W, Rådström P. Purification and characterization of PCR-inhibitory components in blood cells. J Clin Microbiol. 2001;39(2):485-93. doi:10.1128/JCM.39.2.485-493.200

12. Akane A, Matsubara K, Nakamura H, Takahashi S, Kimura K. Identification of the heme compound copurified with deoxyribonucleic acid (DNA) from bloodstains, a major inhibitor of polymerase chain reaction (PCR) amplification. Forensic Sci. 1994;39(2):362-72. doi:10.1520/JFS13607J

13. Satsangi J, Jewell DP, Welsh K, Bunce M, Bell Jl. Effect of heparin on polymerase chain reaction. Lancet. 1994;343(8911):1509-10. doi:10.1016/S0140-6736(94)92622-0

14. Perch-Nielsen IR, Bang DD, Poulsen CR, El-Ali J, Wolff A. Removal of PCR inhibitors using dielectrophoresis as a selective filter in a microsystem. Lab Chip. 2003;3(3):212-6. doi:10.1039/b304549h

15. Brown B, Oberste MS, Maher K, Pallansch MA. Complete genomic sequencing shows that polioviruses and members of human enterovirus species $\mathrm{C}$ are closely related in the noncapsid coding region. J Virol. 2003;77(16):8973-84. doi:10.1128/JVI.77.16.8973-8984.2003

16. Chadwick DR, Lever AML. The impact of new diagnostic methodologies in the management of meningitis in adults at a teaching hospital. QJM. 2000;95(10):663-70. doi:10.1093/qjmed/95.10.663

17. Puchhammer-Stöckl E, Presterl E, Croÿ C, Aberle S, Popow-Kraupp T, Kundi M et al. Screening for possible failure of herpes simplex virus PCR in cerebrospinal fluid for the diagnosis of herpes simplex encephalitis. J Med Virol. 2001;64(40:531-6. doi:10.1002/jmv.1082

18. Vidal LR, Almeida SM, Messias-Reason IJ, Nogueira MB, Debur MC, Pessa LF et al. Enterovirus and herpesviridae family as etiologic agents of lymphomonocytary meningitis, Southern Brazil. Arq Neuropsiquiatr. 2011;69(3):475-81. doi:10.1590/S0004-282X2011000400013

19. Tang YW, Mitchell PS, Espy MJ, Smith TF, Persing DH. Molecular diagnosis of herpes simplex virus infections in the central nervous system. J Clin Microbiol. 1999;37(7):2127-36.

20. Weber T, Frye S, Bodemer M, Otto M, Lüke W. Clinical implications of nucleic acid amplification methods for the diagnosis of viral infections of the nervous system. J Neurovirol. 1996;2(3):175-90. doi:10.3109/13550289609146880 